\title{
Bā čuxe wrestling: a traditional wrestling art from Iran
}

\author{
Manouchehr Moshtagh KHORASANI* \\ Independent researcher (Germany) \\ Recepción: 20/08/2014; Aceptación: 01/11/2014; Publicación: 03/11/2014.
}

\begin{abstract}
There are more than twenty different traditional wrestling arts that are practiced in today Iran. One of them which is

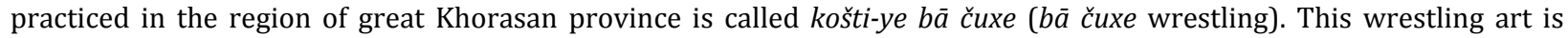
performed by wearing knee-length pants and a thick jacket and is famed for its powerful throws and leg trips. The following article deals with the history of $b \bar{a} \check{c} u x e$ wrestling and its fundamental techniques. First an introduction to this type of wrestling is given. Later the article describes the background and the regions of practice of bā čuxe wrestling. In the next section the rules and regulation of $b \bar{a} \breve{c} u x e$ matches are provided. Then, based on the available literature on the topic and also on fieldwork, the article expands on the fundamental techniques in this traditional wrestling style.
\end{abstract}

Keywords: Bā čuxe wrestling; Khorasan province; traditional wrestling; throws; leg trips; martial arts; wrestling; combat sports.

\section{La lucha Bā čuxe: un estilo de lucha tradicional iraní}

\section{Resumen}

Hoy en día existen en Irán más de veinte estilos de lucha tradicional. Uno de ellos se practica en la gran provincia de Khorasan y se denomina košti-ye bā čuxe (lucha $b \bar{a}$ čuxe). Este estilo de lucha se practica con pantalones cortos hasta las rodillas y una gruesa chaqueta, y se caracteriza por sus potentes proyecciones y sus técnicas de pierna. Este artículo describe la historia de la lucha $b \bar{a}$ čuxe y sus técnicas fundamentales. En primer lugar se introduce este estilo de lucha. Seguidamente se describe el contexto y las zonas en las que se practica. En la siguiente sección se detallan los aspectos reglamentarios de la lucha. Para terminar, sobre la base de la literatura existente sobre el tema y de trabajo de campo, el artículo detalla las técnicas fundamentales de este estilo de lucha tradicional.

Palabras clave: Lucha $b \bar{a}$ čuxe; provincia de Khorasan; lucha tradicional; proyecciones; técnicas de pierna; artes marclaies; lucha; deportes de combate.

\section{Luta Bā čuxe: um estilo de luta tradicional do Irão}

\section{Resumo}

Hoje em dia, existem mais de vinte estilos de luta tradicional no Irão. Um deles pratica-se na grande província de Khorasan e chama-se košti-ye bā čuxe (luta $b \bar{a}$ čuxe). Este estilo de luta pratica-se com calças curtas até aos joelhos e um grosso casaco e caracteriza-se pelas suas potentes projecções e as suas técnicas de pernas. Este artigo descreve a história da luta $b \bar{a} \breve{c} u x e$ e as suas técnicas fundamentais. Em primeiro lugar, introduz-se este estilo de luta. Seguidamente, descreve-se o contexto e as zonas geográficas em que se pratica. Na seguinte secção detalham-se os aspetos regulamentares da luta. Para terminar, e com base na literatura existente sobre o tema e sobre o trabalho de campo, o artigo detalha as técnicas fundamentais deste estilo de luta tradicional.

Palavras-chave: Luta bā čuxe; província de Khorasan; luta tradicional; projecções; técnicas de perna; artes marciais; luta; desportos de combate.

\section{1.- Introduction}

In the region of Khorasan, in the northeast of Iran, different, traditional wrestling matches are practiced. One of the wrestling arts called $b \bar{a} \breve{c} u x e$ has its roots in battlefield preparation techniques as grabbing and throwing techniques are emphasized with a deep standing position. The term $b \bar{a} \breve{c} u x e$ consists of $b \bar{a}$ (with) and čuxe (a type of traditional jacket). There is not international available literature on the topic. $B \bar{a} \check{c} u x e$ is mainly practiced by Kurdish tribes who

*Email: manouchehr@moshtaghkhorasani.com 
reside in Khorasan (Abbāsi, 1995) This type of wrestling is conducted in the cities of Qučān, Bojnord, Asfariyān, Farimān, and Čenārān (all in the region of Khorasan) (Qezel Āyāq, 2000; Mohammad Jahān, 1998). Thus, bā čuxe wrestling takes place in many cities in the province of Khorasan for especial events such as the Persian New Year celebration of Nowruz or other Public holidays and also during wedding ceremonies (Moqqadam Ziyārat, 2004). Note that nowadays the province of Khorasani is divided into three smaller provinces: a) Razavi Province, b) Northern Khorasani and c) Southern Khorasan, and each province has its own championship and then a grand championship in wrestling is held between all provinces to determine the champions in $b \bar{a}$ čuxe wrestling (Moqqadam Ziyārat, 2004). It is also held after harvesting the fields and crops (Abbāsi, 1995). Moqqadam Ziyārat (2004) explains that even Nāder Qoli (1688-1747), the future King and the founder of Afsharid dynasty, was a proficient $b \bar{a} \breve{c} u x e$ wrestler before he was crowned as the king of Persia. Referring to the Lexicon of Nafisi, Abbāsi (1995) explains that that the origin of the word $\check{c} u x e$ was $\check{c} u x \bar{a}$. This is a Persian word in origin. The $b \bar{a} \breve{c} u x e$ wrestling organization regulates and holds local and national championships on this traditional wrestling style in Iran. This is not a professional organization but a local and traditional one which has been trying to adapt the rules to fulfill the requirements for an international competition.

Iranian history reports about the efficiency of $b \bar{a}$ čuxe wrestling. The famed Pahlavān Akbar Khorasāni from the Qajar period (1785-1925) was one of the practitioners of this style. Like many other champion wrestlers, he was a wrestler of traditional Palavāni wrestling styles which were practiced in houses of strength (zurxāne). It is reported that once Pahlavān Akbar Khorasāni travelled from Mashad to Tehran to wrestle and after being defeated, he went back in despair. His coach advised him to train with $b \bar{a}$ čuxe wrestlers in Češme Gilās for six months, as they were proficient in leg tripping techniques and those techniques would make him successful (see Bolur, 1975; Moqqadam Ziyārat, 2004). It is reported that Pahlavān Akbar Khorasāni sold his property to go and train there for six months, where he trained everyday and became proficient in the style and could defeat everyone. Then he returned to Mashad to show the new techniques he had learned. Then his master advised him to challenge the grand champion of Tehran Pahlavān Yazdi. His opponents called him saqpa (dog's leg - the attribute of dog is used to refer to the toughness of something) (Moqqadam Ziyārat, 2004).

Originally, $b \bar{a}$ čuxe wrestlers used their everyday cloth for wrapping up their sleeves and binding their shawl around their waist to wrestle. From 1950, wrestlers started to wear pants reaching down to the knee and a sleeveless jacket. This jacket was made of a very tough wool called čuxe. They also used a shawl as a belt. Starting from 1962, instead of wool they started to use flax, which is still being used as the material for the $b \bar{a}$ čuxe jacket. The wool was made of sheep wool or camel wool (Moqqadam Ziyārat, 2004).

In $b \bar{a}$ čuxe it is forbidden to take the opponent down by grabbing one leg or grabbing the leg below the knee. The wrestler whose shoulder touches the ground will lose the match. It is interesting to see that this match significantly resembles Japanese jujutsu or judo. The combatants in $b \bar{a} \breve{c} u x e$ fight in an upright position, grab the čuxe of their opponent, and try to throw him off balance. The throwing actions of this type of wrestling clearly show the military legacy of this match, where the opponents could have been thrown off balance in close-quarter combat and killed using a dagger (xanjar). Kurdish tribes of Khorasan in Iran practice the čuxe wrestling, but it has been spreading across Iran. The wrestlers perform ritual and religious ablution and pray to God prior to matches and try not to walk directly towards the stars, as they believe this would result in their loss (Abbāsi, 1995).

\section{Aim and method}

The main aim of this paper is to provide a detailed background about the $b \bar{a}$ čuxe wrestling. The research was based on the available literature (all published in Iran), and also fieldwork where a champion of the style was interviewed through a structured interview. This interview was focused on the techniques of $b \bar{a} \breve{c} u x e$ wrestling. Also, he showed the fundamental techniques of the style; these techniques are described and shown in the present article. The comparisons to judo techniques were made by Mohammad Jahāni (1998) and by the author of the present article. 


\section{Current rules and regulations of the match}

Like any other wrestling match, this type of wrestling has its own rules. In the following, the rules and regulations governing the $b \bar{a} \breve{c} u x e$ wrestling matches will be explained. Abbāsi (1995) differentiates between the following regulations for performing $b \bar{a} \breve{c} u x e$ wrestling:

- Rule 1

The clothing for $b \bar{a} \check{c} u x e$ wrestlers is: a) long black pants made of black canvas which will be folded up over the knees before the combat and is called tonbān, b) an undershirt, c) angle wraps called pātābe, d) wool socks, e) leather shoes called čāroq, and e) a shawl serving as a belt, one in red color for one opponent and the other in blue color for another opponent. The shawls are made of wool (before the match the wrestlers take off the socks and shoes) (Moqqadam Ziyārat, 2004).

- Rule 2

Weight classification of wrestlers - In the past, there were no time and weight limits in bā čuxe wrestling. This led to serious injuries and even death. The wrestlers of $b \bar{a}$ čuxe traveled from one village to the other, requesting challenge matches, and they sometimes went to Turkmen villages, asking for challenge matches there as well. The Turkmens of Northern Khorasan held their wrestling matches particularly during their wedding ceremonies. They call their traditional wrestling goraš. Today, wrestlers are grouped into group 1 (adolescents) with a maximum age of 16 and a minimum weight of 40 kilos and group 2 (champions) which has no age limit but the minimum weight is 70 kilos. Starting from 1983, three weight classes were introduced in $b \bar{a}$ čuxe wrestling: up to 70 kilos, 70-80 kilos, and above 80 kilos (heavyweight) (Mohammad Jahāni, 1998). The reason was due to the unfortunate death of a champion named Alirezā Dartumi (Rostami) who was also a champion of freestyle wrestling of the province Khorasan in the category of 74 kilos. He faced an opponent who was 45 kilos heavier and during the match he was unfortunately killed after a devastating throw. Still the new classification does not solve all problems as a person who weighs 81 kilos might still face an opponent of 130 kilos or heavier in a stand-up fight which includes many throws.

- Rule 3

The wrestling matches always start in a standing position. Wrestlers' first actions deal with zurvarzi (testing the strength). This means that the wrestlers grab each other and before applying a technique try to test the strength and base of their opponent to find out the right throwing technique: the wrestlers fold up their pants over their knees, take off their shoes and socks and enter the wrestling ground. The wrestling ground is 12 meters long and 12 meters wide and this is normally outside on a green pasture. The time for wrestling for wrestlers below the age of eighteen is four minutes. If no decision is taken, the wrestlers take two minutes break and then have another four minutes. If no decision is made, then they take a rest of two minutes and then wrestle for three more minutes. If still no decision is made then the referees will call the more aggressive wrestler the winner of the match. The adults wrestle for ten minutes and if no winner can be determined they take a break of two minutes and fight for five more minutes.

In the past, tribesmen, leaders and former champions acted as referees for $b \bar{a}$ čuxe wrestling. Wrestlers fought against each other during a match without a time limit and if a wrestler threw his opponent twice, he could win a match. To call a throw as a valid technique for victory, one had to throw the opponent in a way so that any part of his body besides the feet or palms of the hands, which could be used to avoid a complete throw, touched the ground. Another way is when one throws an opponent in a way that the back of the opponent is completely twisted in the air and his back reaches an angle less than ninety degrees to the ground. As wrestlers knew that after the first throw, they could still fight back for one more time, the wrestling matches were dynamic. Nowadays, as mentioned above, wrestling matches are conducted for a time limit of ten minutes and if no one can win a match, then an extension of five minutes is given (Moqqadam Ziyārat, 2004).

- Rule 4

Requirements for taking part in the matches - One should have qualified in the qualification matches of the city and provide a medical certificate. Weighing the wrestlers will be done on the first day of the matches. All adolescents should provide identification card or birth certificate. 
- Rule 5

Referees - There are five referees for judging the match. One of them stands in the middle of the wrestling ground and the others act as corner judges. All judges swear to be fair and impartial. A majority decision of all judges can decide which wrestler wins the fight.

- Rule 6

How to win a fight: (1) One makes sure that the opponent's shoulder touches the ground; (2) Another way is to turn around the shoulder's axis in the air; (3) One can win a fight if he throws his opponent in a way that his back reaches an angle less than ninety degrees to the ground. In Persian, there is an expression of sāye andāxtan (to cast shadow); (4) Resting on both shoulders on the ground when the wrestler is sitting on his backside; (5) When the shoulders are closer to the ground than the waist after a throw; and (6) when a wrestler constantly attacks and his opponent only escapes then the latter will lose due to the technical superiority of his opponent.

\section{- Rule 7}

Disqualification - (1) A wrestler who is impolite and does not accept the judges' decision will be banned forever from $b \bar{a} \breve{c} u x e$ wrestling federation; (2) Insulting the spectators and the opponent will lead to a disqualification, (3) A wrestler who does not present a medical certificate will be disqualified; (4) All adolescents who are older than 16 years or weigh less than 40 kilos will be disqualified. Adults who weigh less than 70 kilos will be disqualified; and (5) If the referees find out that the wrestlers made an agreement who would win a fight or rigged the match, they disqualify both from the matches forever (Moqqadam Ziyārat, 2004).

\section{- Rule 8}

Illegal techniques - (1) Grabbing the legs below the knees such as ankle pick (bozkeši) or a single leg takedown by pressing the head against the opponent's thigh (miyānkub); (2) High crotch (kalandun) is forbidden, (3) Arm spin throw (pičpičak); (4) Any type of suplex; (5) arm drag and getting the opponent's back (dastu) (for the application of the before-mentioned techniques in freestyle wrestling see Rāygān Tafreši, 2007); (6) Grabbing the jacket of the opponent in a cross hold; (7) Pulling the opponent's jacket over his head; (8) Placing the opponent's leg between one own legs and lock it; and (9) There are no ground techniques unless the wrestlers start on foot and then land on the ground where they can continue for some seconds.

\section{- Rule 9}

Legal techniques - (1) All types of leg tripping (leng kardan); (2) All types of sweeps (fat-e pā); (3) Hip throws (fan-e kamar); and (4) Twisting and locking the arms and hands (qolpic) (this technique is called leng-e a renj - elbow tripping - in freestyle wrestling; for the application of this technique see Rāygān Tafreši, 2007). The main legal techniques in $b \bar{a} \breve{c} u x e$ wrestling will be explained in this article later.

- Rule 10

Prize - For adults the first place gets a mare, the second place receives a dairy cow and the third place gets a ram. The first three places of adolescents get a gold medal each.

- Rule 11

All wrestlers together with their coaches and team members will stay at a training camp close to championships. All accommodation and catering costs for them will be covered one day before and one day after the matches by the $b \bar{a} \breve{c} u x e$ wrestling federation. The travelling costs by bus will be also covered by the federation (see Abbāsi, 1995).

- Rule 12

All matches are accompanied by music performed with two musical instruments, which are a dohol (drum) and a sornā (hautboy) (see Moqqadam Ziyārat, 2004).

\section{Techniques of bā čuxe wrestling}

The similarities between $b \bar{a} \check{c} u x e$ wrestling and judo are such that some of the $b \bar{a} \check{c} u x e$ wrestlers successfully take part in judo championships (Mohammad Jahāni, 1998). One should note that these similarities are in the stand-up fight as in the $b \bar{a} \breve{c} u x e$ wrestling there are no groundfighting and chokes. 
There are four major categories of the techniques of $b \bar{a}$ čuxe wrestling:

(1) techniques predominantly executed with the legs,

(2) techniques predominantly done using hands and arms,

(3) techniques executed predominantly using the neck and the waist, and

(4) mixed techniques where all parts of the body play an important role (Mohammad Jahāni, 1998).

However such a clear-cut classification of $b \bar{a} \check{c} u x e$ wrestling techniques is almost impossible as all parts of the body should be used to apply a technique successfully. Further when an opponent starts the fight with the upper guard (bālädast), the other wrestler is forced to fight with grabbing lower body and upper leg techniques (zirgiri). Mohammad Jahāni (1998) stresses that in contrast to the freestyle wrestling, in $b \bar{a} \breve{c} u x e$ both wrestlers are wearing a jacket and short pants, therefore surprise attacks are very difficult because the opponents can keep each other at distance by holding each other's jackets. Therefore, techniques such as feinting a grab to the head and then lowering the base for applying a single-leg or double-leg takedown as done in freestyle wrestling matches are very hard to do in this type of wrestling. If a wrestler is forced down when the opponent applies pressure on his jacket, he can act in the following ways: (1) going for the lower body and breaking up the balance, or (2) grabbing the thigh and lifting it.

In the following, I will present the classification and identification of techniques of $b \bar{a} \check{c} u x e$ wrestling by Bolur (1975), Moqqadam Ziyārat (2004) and Mohammad Jahāni (1998). It seems there is not a consensus about these techniques. Thus, in the following some classifications of $b \bar{a}$ čuxe wrestling techniques will be shown.

First, Bolur (1975) identifies some techniques in the bā čuxe wrestling: (1) Kandan (lit. "lifting" known as "rear throw"), (2) Leng az jolo (lit. "leg tripping from front" known as "large wheel") or pišleng (frontal leg tripping), (3) Leng az aqab (lit. "leg tripping from the back" known as "belt drop"), (4) Pasleng (lit. "back leg tripping" also known as "large outer drop"), (5) Rudast bālā dast az aqab (lit. "one hand above and one hand from the back" also known as "scoop throw"), and (6) Yānbāš (lit. "leader of the side" also known as "major outer reaping"). Table 1 shows the techniques of $b \bar{a} \breve{c} u x e$ wrestling which are identified by Bolur (1975) and their similarities to the corresponding judo techniques as established by the author of the present article.

Table 1. Techniques of $b \bar{a} c \breve{u x e}$ wrestling according to Bolur (1975), and their similarity with judo techniques.

\begin{tabular}{|c|c|}
\hline Name and description of the technique in $b \bar{a} \breve{c} u x e$ wrestling & Similar technique in judo \\
\hline kandan, lit. "lifting" known as "rear throw" & ushiro goshi \\
\hline leng az jolo, lit. "leg tripping from front" known as "large wheel" & -------- \\
\hline leng az aqab, lit. "leg tripping from the back" known as "belt drop" & obi otoshi* \\
\hline pasleng, lit. "back leg tripping" also known as "lifting pulling ankle drop" & sasae tsurikomi ashi \\
\hline $\begin{array}{l}\text { rudast bālā dast az aqab, lit. "one hand above and one hand from the back" also } \\
\text { known as "scoop throw" }\end{array}$ & sukui nage \\
\hline yānbāš, lit. "leader of the side" also known as "major inner reaping throw" & ouchi gari \\
\hline
\end{tabular}

* However in $b \bar{a} \breve{c} u x e$ wrestling, one uses their own leg for tripping from behind as well.

Second, Moqqadam Ziyārat (2004) distinguishes sixteen techniques in bā čuxe wrestling as shown in Table 2 . He only mentions the names and does not show and explain how these techniques could be applied. But note that most of these techniques are adopted in Iranian freestyle wrestling from the $b \bar{a} \breve{c} u x e$ wrestling. Fortunately, Bolur (1975) shows the application of these techniques in free style wrestling which have been adopted from $b \bar{a} c \check{c} u x e$ wrestling. Table 2 shows the application of these techniques in detail and their similarity with judo techniques as established by the author of the present article. 
Table 2. Techniques of $b \bar{a} \breve{c} u x e$ wrestling according to Moqqadam Ziyārat (2004), and their similarity with judo techniques.

\begin{tabular}{|c|c|}
\hline Name and description of the technique in $b \bar{a} \breve{c} u x e$ wrestling & Similar technique in judo \\
\hline $\begin{array}{l}\text { čenärandāz, lit. "chopping the plane tree". To perform this technique one holds } \\
\text { the left arm of the opponent in an underhook position by the right arm below } \\
\text { his armpit and then grabs his left thigh with the left hand and then wraps one's } \\
\text { own right leg around his left leg from outside and reaps the opponent down. }\end{array}$ & \\
\hline $\begin{array}{l}\text { gavtāb, lit. "twisting the oxen". To execute this technique one has both arms of } \\
\text { the opponent in underhook position and the head of the opponent is below } \\
\text { one's own left armpit. One is holding his hands in a wrestling lock position. By } \\
\text { twisting the opponent's body to the left, one trips his front leg at the same time } \\
\text { so that he falls. }\end{array}$ & --------- \\
\hline $\begin{array}{l}\text { kandan, lit. "lifting" (known as "rear throw") with different varieties yekpā (on } \\
\text { one leg), dopā (on two legs), deraxtkan (uprooting the tree). }\end{array}$ & ushiro goshi \\
\hline kulandāz, lit. "shoulder throw". & seoi nage a \\
\hline $\begin{array}{l}\text { leng-e ärenj, lit. "leg tripping and the elbow". To apply this technique one holds } \\
\text { the opponent's right arm with the left hand and then one turns and brings the } \\
\text { right arm above the opponent's right arm in the overhook position, locks it } \\
\text { there and then trips his right leg with one's own right leg by twisting the hip. }\end{array}$ & yama $\operatorname{arash}^{\mathrm{b}}$ \\
\hline $\begin{array}{l}\text { leng-e dodast yekdast az vasat-e pā, lit. "leg tripping by holding two arms and } \\
\text { one arm in the middle of the leg". To execute this technique one holds both } \\
\text { opponent's arms under the right armpit and then turns to trip his right leg with } \\
\text { one's own leg and at the same time one goes down to grab the right knee of the } \\
\text { opponent to push him down. }\end{array}$ & -------- \\
\hline leng-e kamar, lit. "waist tripping", known as "sweeping hip throw" & haraigoshi \\
\hline $\begin{array}{l}\text { leng-e maqrebi, lit. "western leg tripping". One grabs the right arm of the } \\
\text { opponent in an underhook position below his armpit by turning the body and } \\
\text { spreads his right leg and pulls him down to fall down. }\end{array}$ & seoi otoshic \\
\hline $\begin{array}{l}\text { leng-e rudast bālā dast māye-ye yānbāš, lit. "leg tripping with the hand from } \\
\text { above applying leader of the side". To apply this technique, one holds the head } \\
\text { of the opponent and his right arm/shoulder below the right armpit and then } \\
\text { trips his left leg by one's own right leg around the knee area. Then one applies } \\
\text { pressure and bends down and grabs the right knee of the opponent and throws } \\
\text { him down. }\end{array}$ & \\
\hline $\begin{array}{l}\text { leng-e sarkes or leng-e pišro, lit. "power leg tripping" or "frontal leg tripping", } \\
\text { known as "hip wheel". }\end{array}$ & koshi guruma ${ }^{\mathrm{d}}$ \\
\hline $\begin{array}{l}\text { palangšekan, lit. "breaking the leopard". One holds the waist and arms of the } \\
\text { opponent in the overhook position and applies pressure. Then one hooks one's } \\
\text { own right leg and wraps it around the opponent's left leg and by applying }\end{array}$ & \\
\hline
\end{tabular}
pasleng, lit. "back leg tripping", also known as "lifting pulling ankle block" with two variations of pasleng dar dāxel-e moč-e pā ("back leg tripping inside the ankle" and pasleng az tarafeyn-e moč-e pa ("back leg tripping outside the sasae tsurikomi ashi ankle").

pičidan, lit. "twisting". One locks the opponent's leg with one's own leg and then by raising the same leg to the back or front, the opponent is thrown; this technique is also known as "valley drop"

qolpič, lit. "twisting and locking", known as "spring wrap around throw".

tani otoshi tābāndān, lit. "twisting". One grabs the body of the opponent by both arms, twists and throws him to the side.

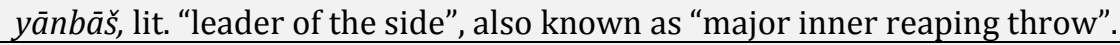
ouchi gari

However in bā čuxe wrestling: (a) one makes an underhook under the armpit of the opponent; (b) one holds the right arm of the opponent in an overhook position tightly; (c) the right arm is in the position of morote seoi nage meaning it is hooked below the right armpit of the opponent; (d) one holds the opponent's neck by both hand holding his neck in a strong lock; and (e) the right hand is wrapped around the opponent's right arm and holds it tight 
Finally, Mohammad Jahāni (1998) mentions the following techniques in bā čuxe wrestling and compares them to some judo techniques (Table 3).

Table 3. Techniques of bā čuxe wrestling according to Mohammad Jahāni (1998), and their similarity with judo techniques.

\begin{tabular}{|c|c|}
\hline Name and description of the technique in $b \bar{a}$ čuxe wrestling & Similar technique in judo \\
\hline kandan, lit. "lifting" known as "rear hip throw" & ushiro goshi \\
\hline leng-e vasat, lit. "inner leg tripping" known as "inner thigh throw" & uchi mata \\
\hline leng-e kamar, lit. "waist tripping" known as "sweeping hip throw" & harai goshi \\
\hline pas lang dar čuxe, lit. "behind the leg in čuxe" known as "small inner reap" & kouchi gari \\
\hline qofle nesbat-e pa, lit. "Locking related to the leg" & kosoto gari \\
\hline qolpič dar čuxe, lit. "hooking in čuxe" known as "large inner reaping" & ouchi gari \\
\hline $\begin{array}{l}\text { yān be surat-e čapbekan dar pošt, lit. "Side in form of lifting from the left to } \\
\text { the back" known as "large outer reaping" }\end{array}$ & osoto gari \\
\hline yān-e kamar dar čuxe, lit. "side of the waist in čuxe" known as "large wheel" & o guruma \\
\hline
\end{tabular}

Next to the above-mentioned techniques, in August 2013, I made a research trip to Bojnord, Khorasan. There I met Pahlavān Hāšem Asadi, one of the most famed champions of $b \bar{a}$ čuxe wrestling. Together, with his senior student Mr. Behnām Bāqčeqi he showed the fundamental techniques of $b \bar{a} \check{c} u x e$ wrestling as practiced in the traditional $b \bar{a} \breve{c} u x e$ wrestling federation of Iran. Next a description of these techniques is provided (see Appendix for pictures, and for the application of these techniques see https://www.youtube.com/watch?v=4ddN7NoyIYY):

(1) čapbekan / sartah (lifting from the left / reversing) (pictures 1-2). Both wrestlers are holding each other's jacket. One places his right leg forward and stretches his right arm over the opponent's body holding the belt in the middle. Then presses the back of the opponent down using one's elbow and holds the opponent's pants with the left arm. The opponent reacts by trying to straighten his body up. Using the force of the opponent, one steps with the left leg forward placing it between the opponent's legs. Then steps between the opponent's legs with the right leg by raising it up and lifting him up, and throws the opponent over one's right leg,

(2) deru kardan joftepa (sweeping both legs) (pictures 3-4). This technique is used as a counter attack against the technique čapbekan (sartah). The opponent is holding one's belt in the middle of the belt and his jacket. One stretches the right arm and holds the opponent's left arm with the right hand. Then one grabs the opponent's pants with the left hand and pushes the back of the opponent with one's own head to prevent him from getting close and applying the technique of čapbekan. Then one releases one`s own head from this position and steps in with the right leg behind the opponent's back and legs and then trips the opponent down with the left leg.

(3) kandan (lifting) (pictures 5-6). This technique is used as a counter to the technique leng-e kamar and is similar to the technique ushiro goshi in judo. Both opponents have their right leg forward grabbing each other's jacket. The opponent steps in with the right leg stretching his right arm over the right shoulder of the defender and manages to grab the belt in the back. From this position, the opponent is able to easily execute the technique leng-e kamar. To prevent this, one should hold the opponent's belt with the left hand first and then stretch the same hand and grab the opponent's pants on the left side from behind. Then one stretches the right arm which was originally holding the opponent's jacket and holding his left arm behind the jacket. Then one steps back with the right leg and then steps forward with the right leg placing it next to the right leg of the opponent. Then, one follows with the left leg and places it next to the right leg of the opponent. In this position, one has one's own legs placed next to each other. Then one trips the opponent's leg with the right foot and throws him to the ground. 
(4) kulandāz (shoulder throw) (pictures 7-8). One is holding the opponent's jacket. The one holds the collar of the opponent's jacket on the right side and pulls him down. When the opponent is forced down, he tries to straighten his body to counter. Then one uses this momentum by holding the jacket of the opponent as described before and then one turns one's own upper body and places the right elbow below the right armpit of the opponent. One turns and looks over the left shoulder and with the strike of the hip and back, one throws the opponent down. This technique is similar to the judo technique seoi nage.

(5) leng-e kamar (hip throw) (pictures 9-10). This technique starts with gärdgiri which means "keeping the guard". This is a basic guard in this type of wrestling where both opponents grab each other's jacket. As the jacket has very short sleeves, one can either hold the top of the jacket behind the neck, the collar side or the lowest part of the sleeve. From the basic guard one opens the hand and brings the right hand over the right shoulder of the opponent and slides it over the opponent's shoulder. This technique is called bālädast. Note that both wrestlers are standing with their right leg forward. Then one grabs the middle of the belt of the opponent over his shoulder on the back. To defend against the hip throw the opponent steps back with his right leg or change the position of the legs. A throw is still feasible from this position provided one holds the belt tight and presses with the right elbow on the back of the opponent with the right hand with the palm facing the opponent's back and his sleeve with the left hand. Then one can approach the opponent by a sudden move and turn and hook the inner side of one own's right leg on the outside part of the left leg of the opponent. Then one trips the leg of the opponent by bringing up one own's leg and continues to do this move. One continues this technique until the opponent falls down. This technique is similar to harai goshi in judo.

(6) leng-e vasat (inner thigh throw) (pictures 11-12). This technique also begins with gārdgiri (keeping the guard). There are two versions of this technique. In the first version, one has his right leg positioned forward whereas the opponent has his left leg positioned forward. With the right hand, one grabs the top of the jacket of the opponent and with the left hand, one holds the right sleeve of the opponent. Then with the left leg one crosses the right leg and positions it behind the right leg. The next step involves placing the right leg between the opponent's leg and by raising the leg, one throws the opponent. Another variation of the technique leng-e vasat involves crossing with the left leg first and then placing the right leg between the opponent's legs and then throwing him to the ground. A similar technique in judo exists as well named uchi mata.

(7) pas-e pā (behind the leg) (pictures 13-14). To apply this technique, one grabs the opponent and pulls him to the left and then suddenly changes the direction by sweeping the opponent's left ankle with one's own right foot. One keeps sweeping until both opponent's legs are in the air and the opponent is thrown to the ground. This technique is similar to the judo technique deashi harai.

(8) pasleng (back leg tripping) (pictures 15-16). To apply this technique, one has the right leg forward and the opponent has his left leg forward and the opponents are grabbing each others' jackets. Then one steps in with the left leg towards the right leg of the opponent and twists the opponent to the right, placing his right foot on the opponent's right ankle and sweeping him down. For a similar technique in judo see sasae tsurikomi ashi.

(9) qolpič az ruberu (armlock from the front) (pictures 17-18). One is holding the jacket of the opponent by gripping his collar behind the opponent's neck with the right hand. The left hand is holding the right sleeve of the opponent. One changes the place of the right hand and holds the jacket of the opponent on the right shoulder. One brings the opponent's upper body close by pulling him close and then grabs his belt with the left hand. Then one places the right leg between the opponent's legs and then places it behind his left leg. At the same time one presses the opponent's throat with the right elbow and throws him down. A similar technique named ouchi gari exists in judo as well.

(10) qolpič dast va pā (locking the arm and the leg) (pictures 19-20). The opponents are holding each other by holding the jacket. One loosens the right hand and locks the left elbow of the opponent by grabbing the right arm around it and holds the opponent's jacket. Then one hooks 
the left leg of the opponent with the right leg and places his left hand on the ground. One keeps raising the right leg up until the opponent falls down. A similar technique in judo is called osoto makikomi (major outer wraparound) where instead of the left leg, the right leg of the opponent is attacked and swept.

(11) yān (side) (see pictures 21-22). Both opponents are holding each other's jackets. One is having his right leg in front. Then one steps with the left leg to the right side of the opponent and then sweeps the right leg of the opponent with the right leg and bring him down. For a similar technique in judo see osoto guruma.

Table 4 shows a list of all 30 techniques as described in literature on $b \bar{a} \check{c} u x e$ wrestling and practiced in $b \bar{a}$ čuxe wrestling federation today.

Table 4. Techniques of $b \bar{a} \check{c} u x e$ wrestling as described in literature and practiced in $b \bar{a} \check{c} u x e$ wrestling federation today.

\begin{tabular}{|c|c|c|}
\hline $\begin{array}{c}\text { Name of the technique in } b \bar{a} \text { čuxe } \\
\text { wrestling }\end{array}$ & $\begin{array}{l}\text { Similar technique } \\
\text { in judo }\end{array}$ & Source \\
\hline čapbekan or sartah & & Pahlavān Hāšem Asadi \\
\hline čenārandā $z$ & 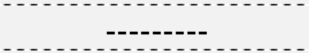 & Moqqadam Ziyārat (2004) \\
\hline deru kardan joftepa & (n) & Pahlavān Hāšem Asadi \\
\hline$g \bar{a} v t \bar{a} b$ & & Moqqadam Ziyārat $(2004)$ \\
\hline kandan & ushiro goshi & $\begin{array}{l}\text { Bolur (1975); Moqqadam Ziyārat (2004); } \\
\text { Mohammad Jahāni (1998); Pahlavān Hāšem }\end{array}$ \\
\hline kulandāz & seoi nage & $\begin{array}{c}\text { Moqqadam Ziyārat (2004); Pahlavān Hāšem } \\
\text { Asadi }\end{array}$ \\
\hline leng az jolo & 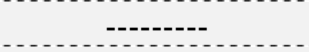 & Bolur (1975) \\
\hline leng $a z a q a b$ & obi otoshi & Bolur (1975) \\
\hline leng-e ärenj & yama arashi & Moqqadam Ziyārat (2004) \\
\hline leng-e dodast yekdast az vasat-e pā & - & Mogqadam Ziyāarat (2004) \\
\hline leng-e kamar or leng-e čuxe & haraigoshi & $\begin{array}{l}\text { Moqqadam Ziyārat (2004); Mohammad Jahāni } \\
\text { (1998); Pahlavān Hāšem Asadi }\end{array}$ \\
\hline leng-e maqrebi & seoi otoshi & Moqqadam Ziyāarat $(2004)$ \\
\hline $\begin{array}{l}\text { leng-e rudast bālā dast māye-ye } \\
\text { yānbāšs }\end{array}$ & --------- & Moqqadam Ziyārat (2004) \\
\hline leng-e sarkeš or leng-e pišro & koshi guruma & Moqqadam Ziyārat $(2004)$ \\
\hline leng-e vasat & uchi mata & $\begin{array}{c}\text { Mohammad Jahāni (1998); Pahlavān Hāšem } \\
\text { Asadi }\end{array}$ \\
\hline palangšekan & - n & Moqqadam Ziyārat $(2004)$ \\
\hline pas-e pā & deashi harai & Pahlavāan Hāšsem Asadi \\
\hline pasleng & $\begin{array}{l}\text { sasae tsurikomi } \\
\text { ashi }\end{array}$ & $\begin{array}{l}\text { Bolur (1975): Moqqadam Ziyārat (2004); } \\
\text { Pahlavān Hāšem Asadi }\end{array}$ \\
\hline pasleng dar cuxe & kouchi gari & Mohammad Jahāni (1998) \\
\hline pičidan & tani otoshi & Mogqadam Ziyārat (2004) \\
\hline gofle nesbat-e pā & kosoto gari & Mohammad Jahāni (1998) \\
\hline golpič & hane makikomi & Moqqadam Ziyārat $(2004)$ \\
\hline qolpič dar čuxe or qolpič az ruberu & ouchi gari & $\begin{array}{c}\text { Mohammad Jahāni (1998); Pahlavān Hāšem } \\
\text { Asadi }\end{array}$ \\
\hline qolpič dast va pā & osoto makikomi & Pahlavān Hāšem Asadi \\
\hline rudast bālā dast az aqab & sukui nage & Bolur (1975) \\
\hline tābāndān & - & Moqqadam Ziyārat (2004) \\
\hline yān & Osoto guruma & Pahlavānn Hāšem Asadi \\
\hline yān be surat-e čapbekan dar pošt & osoto gari & Mohammad Jahāni (1998). \\
\hline yān-e kamar dar cuxe & o guruma & Mohammad Jahāni (1998) \\
\hline yānhbās & ouchi gari & Bolur (1975); Moqqadam Ziyārat (2004) \\
\hline
\end{tabular}




\section{5.- Conclusion}

This article analyzed the history and also the fundamental techniques of $b \bar{a}$ čuxe wrestling, an effective and popular traditional wrestling art of Iran. Many $b \bar{a} \breve{c} u x e$ wrestlers take part in judo championships successfully. One should note that there is not a consensus among authors regarding the corpus techniques of this wrestling style, but one can establish only similarities for the present time. Future research should analyze more subtle techniques and also training methods of $b \bar{a} \breve{c} u x e$ wrestling in more detail. A systematic terminology of $b \bar{a} \breve{c} u x e$ wrestling, based on different areas where this art is practiced, should be established. The roots of this wrestling art should also be analyzed in more detail.

\section{References}

Abbāsi, Mehdi (1995). Tārix-e Košti-ye Irān [The History of Wrestling in Iran]. Second Volume. Tehrān: Entešārāt-e Ferdos.

Bolur, Habibollāh (1975). Fan va Band-e Košti [Wrestling Techniques]. Tehrān: Entešārāt-e Madreseye Āli-e Varzeš.

Mohammad Jahāni, Ali (1998). Košti-ye Kordi-ye bā čuxe [The Kurdish-style Wrestling of bā čuxe]. Tehran: Našre Beh Āfarin.

Moqqadam Ziyārat, Abāsqoli Hušmand (2004). Tārix-e Moxtasar-e Košti-ye Bā Čuxe (A Short History of Bā Čuxe Wrestling). Tehran: Sepās.

Qezel Āyāq, Sorayā (2000). Rāhnamāye Bāzihāye Irān [A Guide to Iranian Games]. Tehran: Daftar Pajuheshhaye Farhangi.

Rāygān Tafreši, Abolqāsem (2007). Ganjine-ye Fonun-e Košti-ye Āzād va Farangi (A Thesaurus of Freestyle and Greco-Roman Wrestling Techniques). Tehran: Safir Ardahāl Publications.

\section{Author's biographical data}

Dr. Manouchehr Moshtagh Khorasani (Germany) has written five books (four related to arms and armor), co-authored one book, and 139 print articles on Persian arms and armor published in different journals across the world. His books include Persian Archery and Swordsmanship: The Historical Martial Arts of Iran, Lexicon of Arms and Armor from Iran: A Study of Symbols and Terminology (Winner of the World Book Prize of the Islamic Republic of Iran 2012), Antique Oriental and Arab Weapons and Armour: The Streshinskiy Collection, The Development of Controversies: From the Early Modern Period to Online Discussion Forums and Arms and Armor from Iran: The Bronze Age to the End of the Qajar Period (Winner of the World Book Prize of the Islamic Republic of Iran 2009). He is the founder and an active member of Razmafzar Organization dedicated to the study and academic research on historical Persian arms and armor and martial arts. E-mail: manouchehr@moshtaghkhorasani.com. 


\section{Appendix}
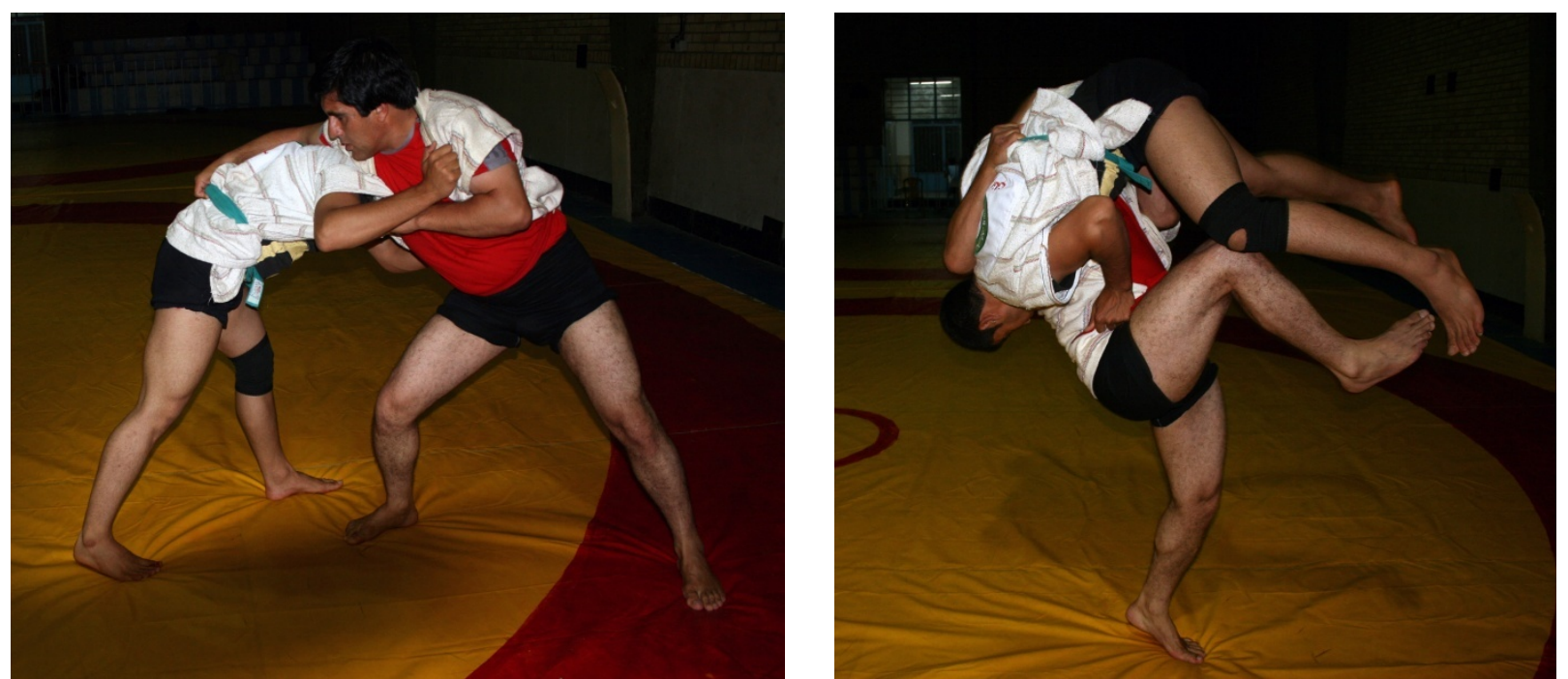

(1) čapbekan / sartah (lifting from the left / reversing).
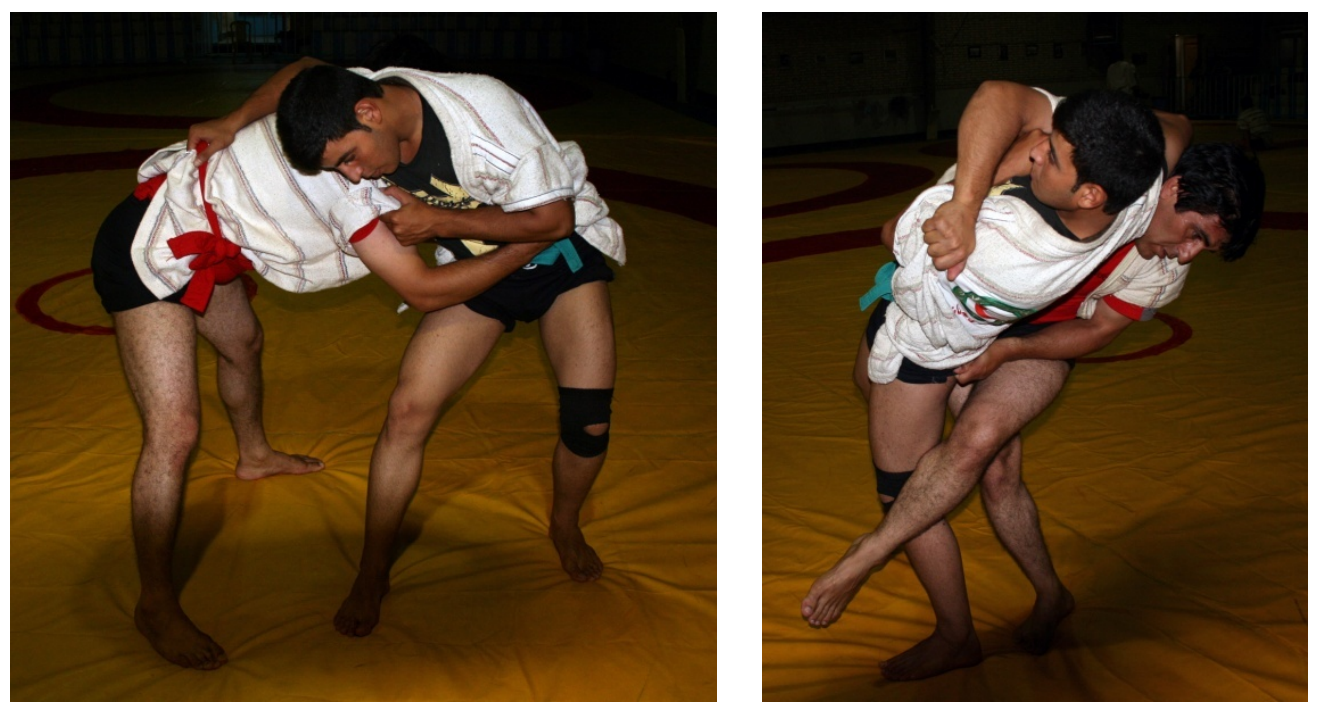

(2) deru kardan joftepā (sweeping both legs).
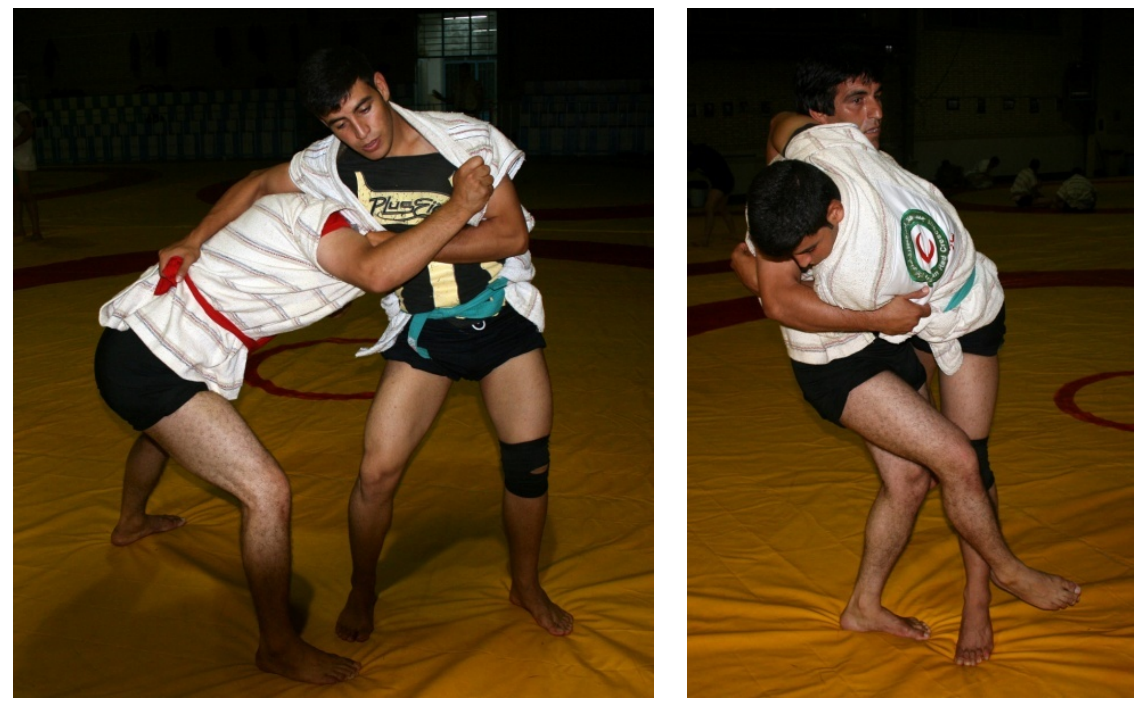

(3) kandan (lifting). 

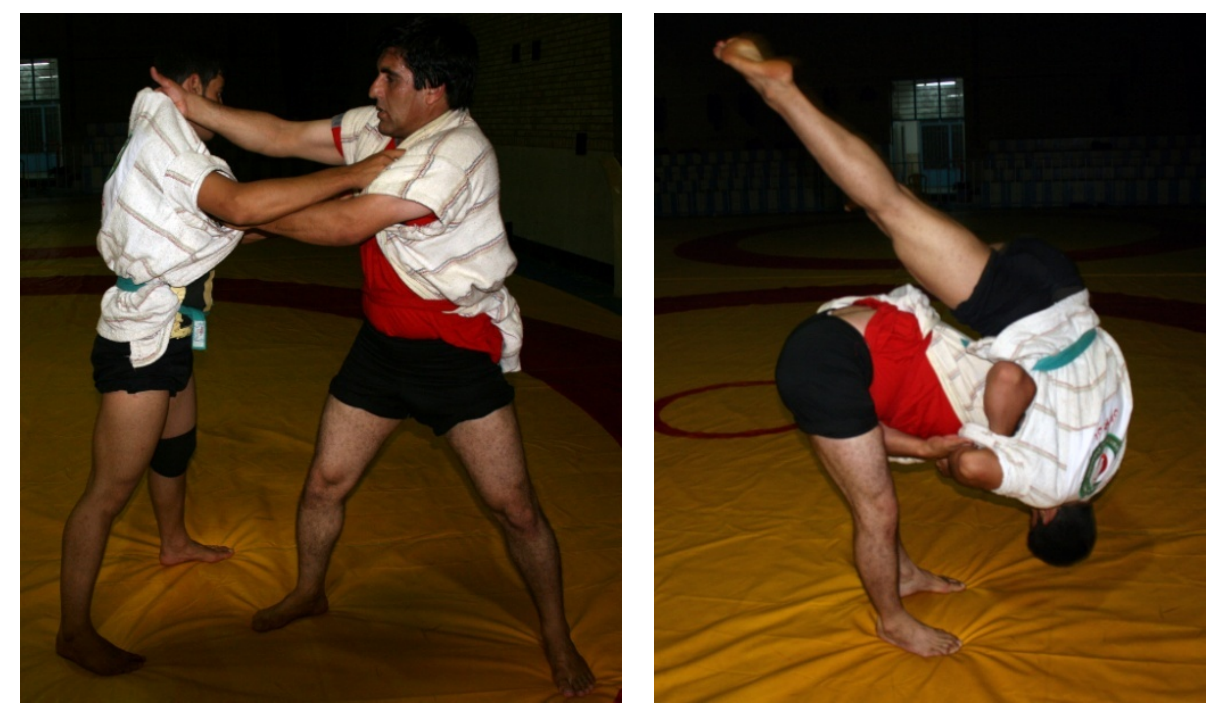

(4) kulandāz (shoulder throw).
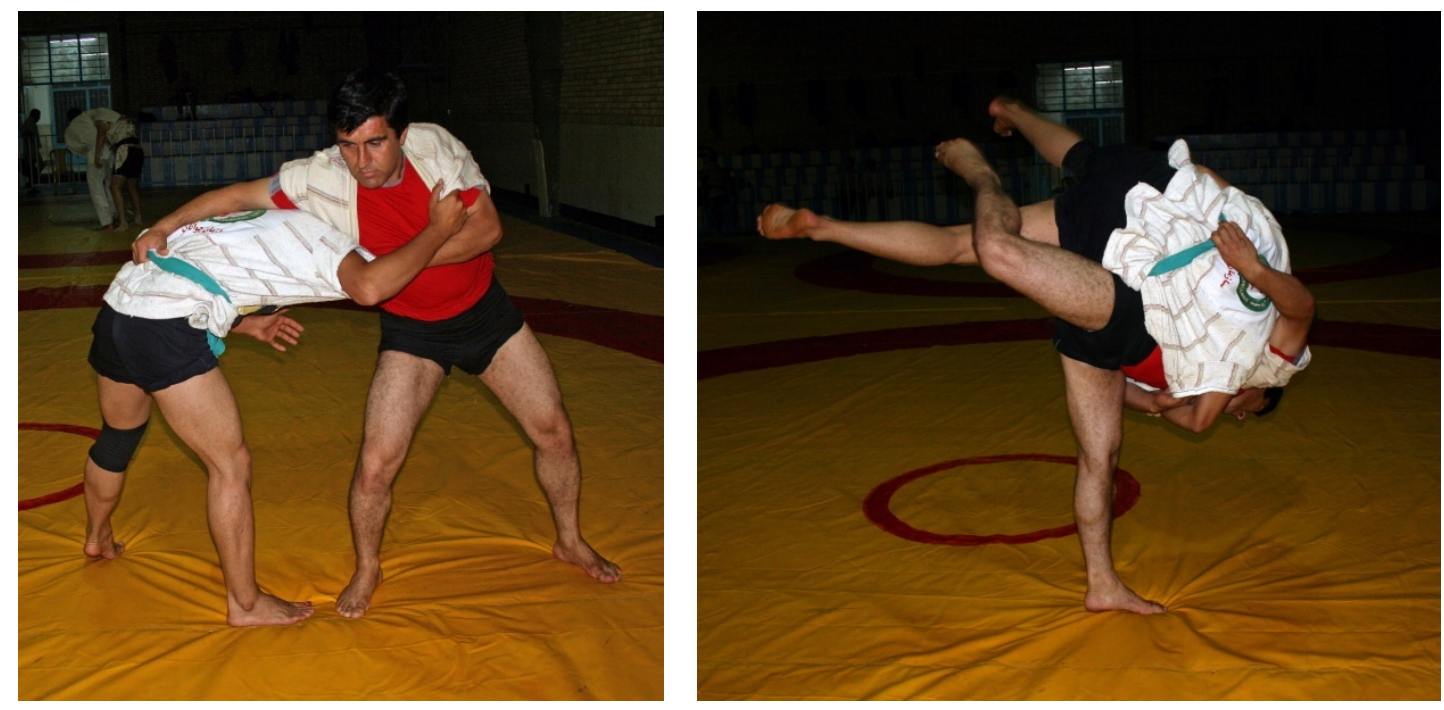

(5) leng-e kamar (hip throw).
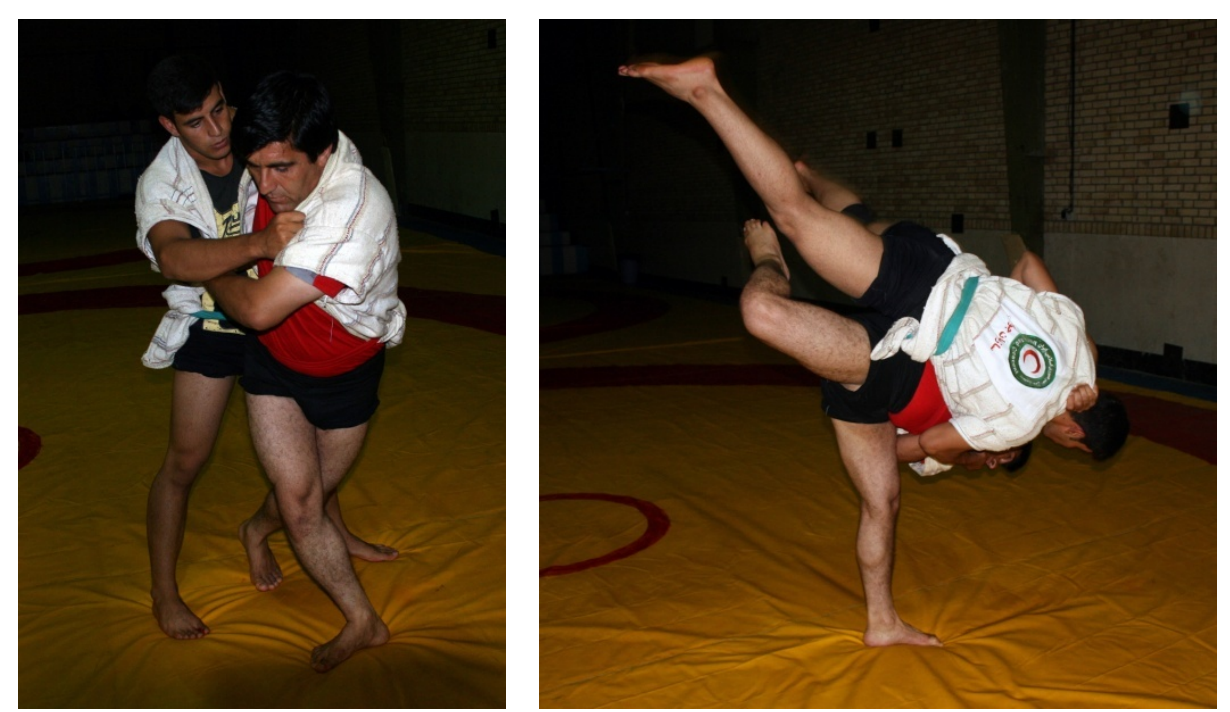

(6) leng-e vasat (inner thigh throw) (pictures 11-12). 

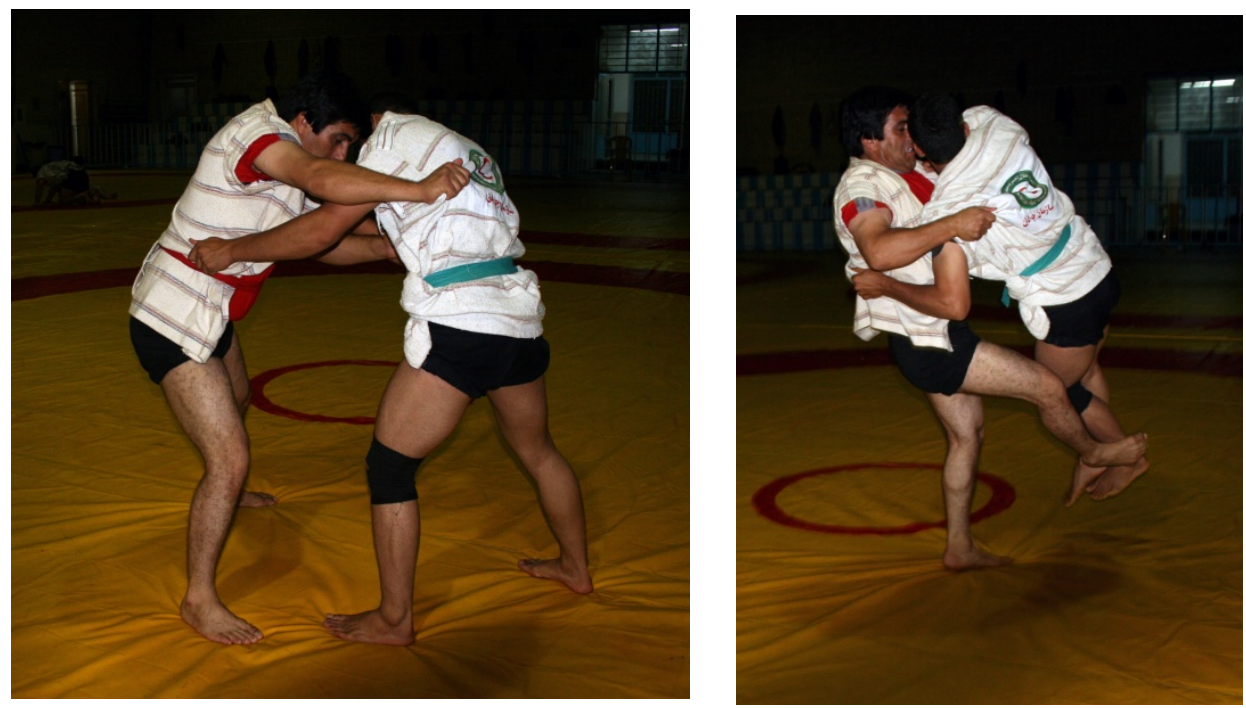

(7) pas-e pā (behind the leg).
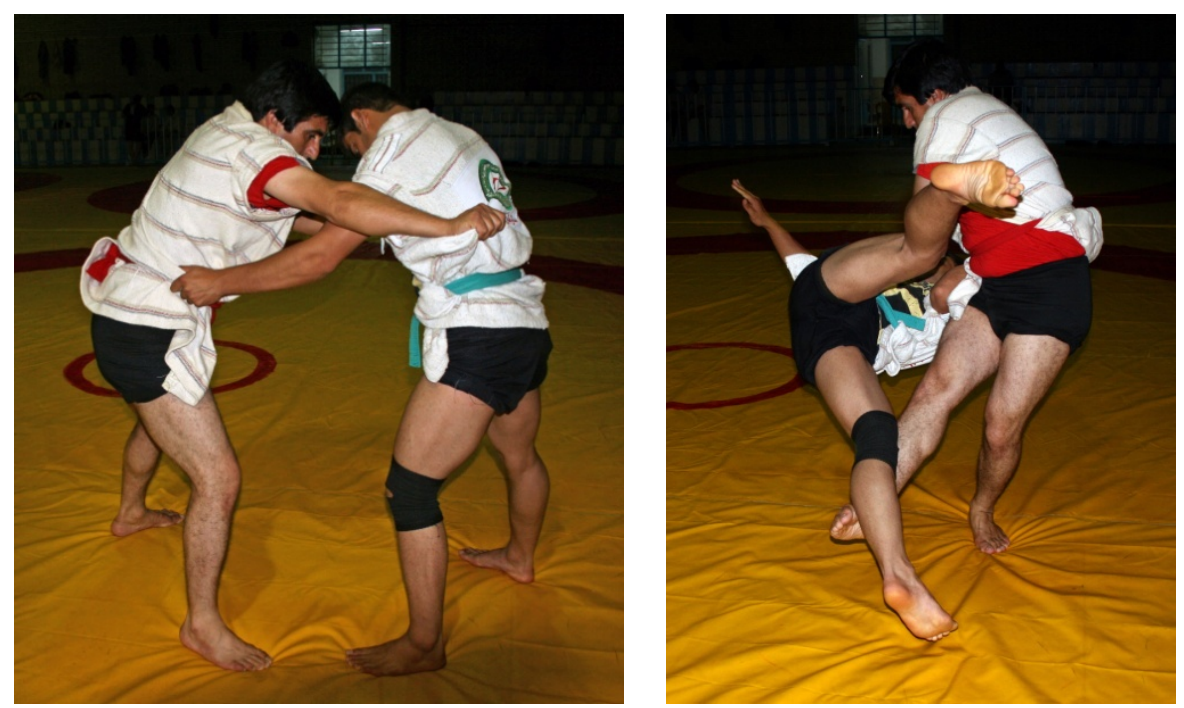

\section{(8) pasleng (back leg tripping).}
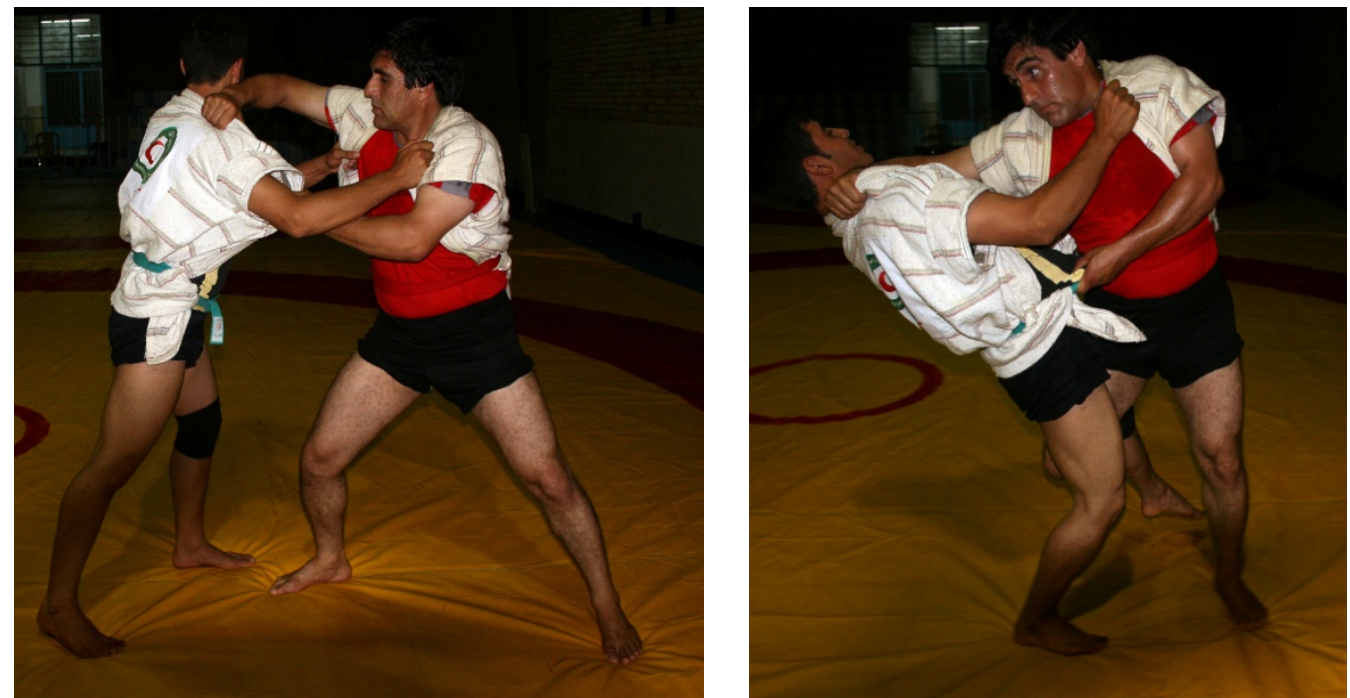

(9) qolpič az ruberu (armlock from the front). 

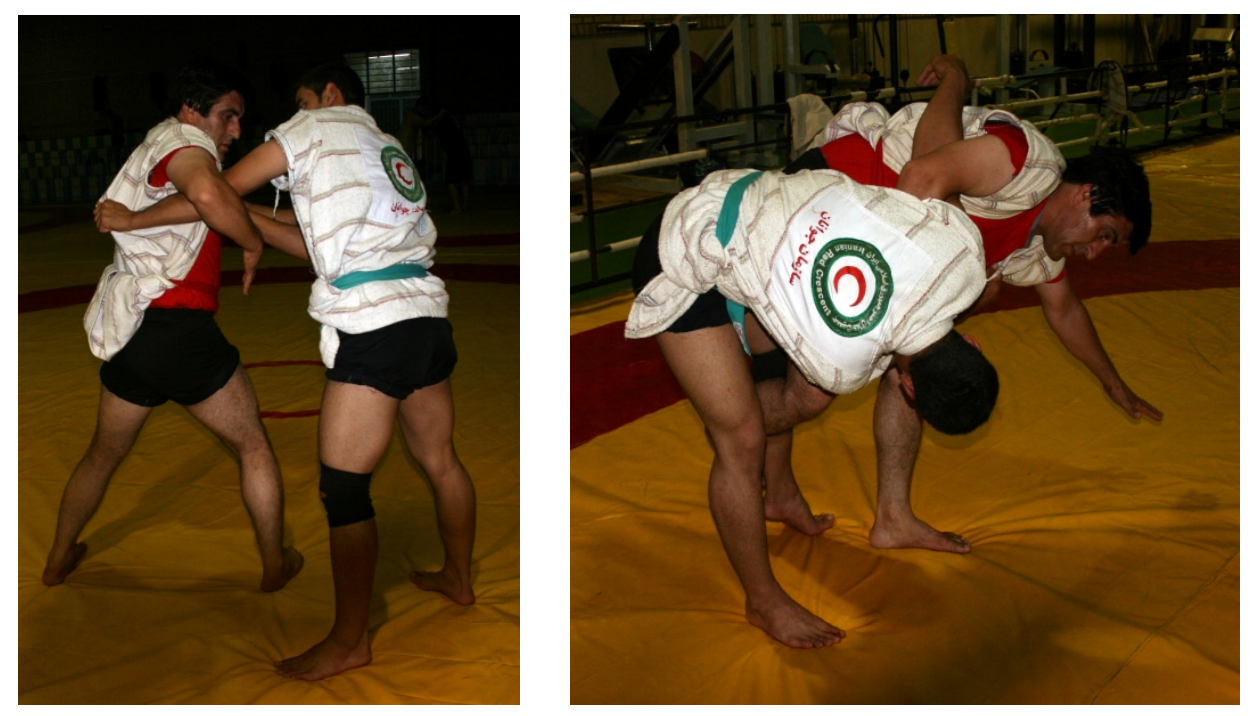

(10) qolpič dast va pā (locking the arm and the leg).
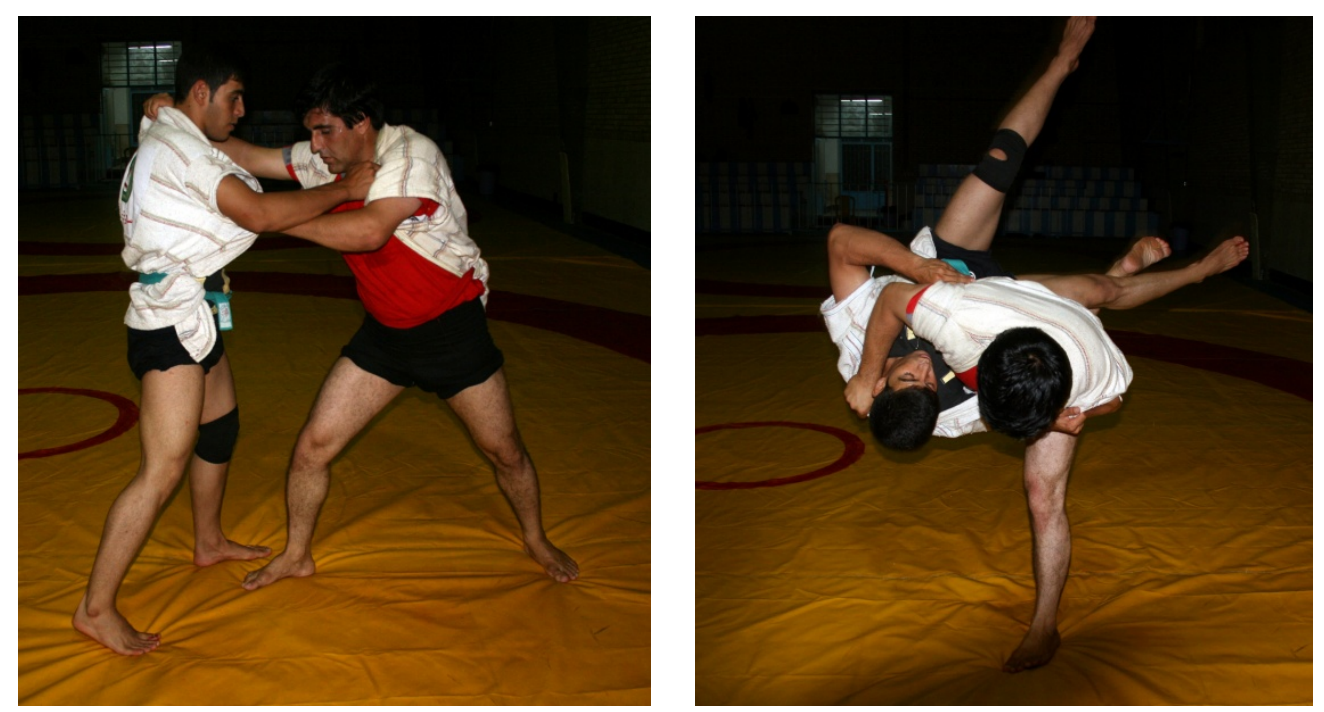

(11) yān (side) (see pictures 21-22). 